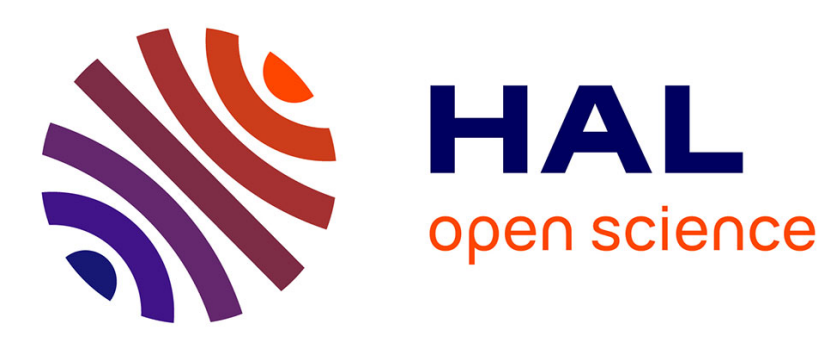

\title{
Mereological essentialism, composition, and stuff: a reply to Kristie Miller
}

David Nicolas

\section{To cite this version:}

David Nicolas. Mereological essentialism, composition, and stuff: a reply to Kristie Miller. Erkenntnis, 2009, 71 (3), pp.425-429. 10.1007/s10670-009-9185-7 . ijn_00420383

\section{HAL Id: ijn_00420383 \\ https://hal.science/ijn_00420383}

Submitted on 28 Sep 2009

HAL is a multi-disciplinary open access archive for the deposit and dissemination of scientific research documents, whether they are published or not. The documents may come from teaching and research institutions in France or abroad, or from public or private research centers.
L'archive ouverte pluridisciplinaire HAL, est destinée au dépôt et à la diffusion de documents scientifiques de niveau recherche, publiés ou non, émanant des établissements d'enseignement et de recherche français ou étrangers, des laboratoires publics ou privés. 


\title{
Mereological essentialism, composition, and stuff: a reply to Kristie Miller
}

\author{
David Nicolas $^{1}$
}

\section{To appear in the journal Erkenntnis}

\begin{abstract}
In 'Essential stuff' (2008) and 'Stuff' (2009), Kristie Miller argues that two generally accepted theses, often formulated as follows, are incompatible:

- (Temporal) mereological essentialism for stuff (or matter), the thesis that any portion of stuff has the same parts at every time it exists.

- Stuff composition, the thesis that for any two portions of stuff, there exists a portion of stuff that is their mereological sum (or fusion).

She does this by considering competing hypotheses about stuff, trying to prove inconsistency in all cases and with all corresponding understandings of mereological essentialism and stuff composition. I explain why, from an endurantist standpoint, her argument does not go through.
\end{abstract}

\section{Introduction}

In recent work (2008, 2009), Kristie Miller considers two theses, which are often characterized in the following manner:

- (Temporal) mereological essentialism for stuff (or matter), the thesis that any portion of stuff has the same parts at every time it exists. ${ }^{2}$

- Stuff composition, the thesis that for any two portions of stuff, there exists a portion of stuff that is their mereological sum (or fusion).

She argues that these two generally accepted principles ${ }^{3}$ are incompatible, and that, given the plausibility of stuff composition, we should conclude that mereological essentialism for stuff is false. She does this by considering competing hypotheses about stuff. She attempts to establish incompatibility in all possible cases, in particular whether one is a perdurantist or an endurantist. Her argument is also meant to apply independently of one's preferred semantics for mass nouns (e.g. a semantics based on mereology or plural reference) and one's corresponding understandings and formulations of mereological essentialism and stuff composition.

The details of Miller's demonstration vary with the alternative conceptions of stuff she considers. But at heart, the basic set-up of her argument remains the

\footnotetext{
${ }^{1}$ Institut Jean Nicod (ENS-EHESS-CNRS), dnicolas@gmx.net

2 This could also be called 'mereological constancy', in order to distinguish it from the stronger claim that any portion of stuff has the same parts at every time it exists, in every world in which it exists.

${ }^{3}$ Cf. Zimmerman (1995) and Markosian (2004).
} 
same. In what follows, I reply from the standpoint of an endurantist about material objects and stuff. Endurance corresponds to an ordinary view of material objects, objects that exist during a certain period. Under this view, a material object like a chair exists for a while, being "wholly present" at any time at which it exists; it has spatial parts, but no temporal parts. The same is true of any portion of stuff, like some wood: it exists for a while, being wholly present; it has spatial parts, but no temporal parts.

In the first section of this note, I present Miller's argument, then show that it is based on a questionable assumption, left unmotivated by Miller. In the second section, I show that our use of mass nouns denoting stuff does provide evidence in favor of this assumption if one adopts a semantics of mass terms based upon mereology. I then explain how a recent account of mass expressions (cf. Nicolas 2008) allows an endurantist to maintain mereological essentialism as a thesis about an entity and its parts, while understanding stuff composition as a thesis about how mass nouns refer, thereby avoiding inconsistency between the two principles.

\section{Section 1}

Miller's argument can be explained with the following example, which is similar to the one she uses (the world $\mathrm{W}_{3}$ described on page 59) ${ }^{4}$, but simpler in that it doesn't presuppose that stuff is composed of mereological atoms. ${ }^{5}$ Consider three succeeding moments of time, $t_{1}, t_{2}$, and $t_{3}$. Some stuff $x$ (which may be some wine, if one wants a concrete example) exists from $t_{1}$ until $t_{2}$, being destroyed at $t_{2}$. Some stuff y (which may also be some wine) exists from $t_{1}$ to $t_{3}$, having no part in common with $\mathrm{x}$. The principle of stuff composition entails that there exists some stuff $\mathrm{z}$ that is the mereological sum of $\mathrm{x}$ and $\mathrm{y} .{ }^{6}$ " $\mathrm{x}$ and $\mathrm{y}$ are parts of $\mathrm{z}$ simpliciter", says Miller (page 59), "and so in a sense, the parts of $\mathrm{z}$ do not change." But "this tenseless sense in which [z] does not lose parts is not the sense we mean to employ when we say that portions of stuff" always have the same parts. Rather, we mean that the parts some stuff has at some time (parts that exist at that time) are identical to the parts it has at any other time at which it exists. And under this sense, Miller continues, $\mathrm{z}$ has different parts at different times. The parts it has at $\mathrm{t}_{1}$ are those of $\mathrm{x}$ and $\mathrm{y}$ and mereological sums thereof. While at $\mathrm{t}_{3}$, its parts are only those of $y$, since $x$ doesn't exist anymore. Hence, mereological essentialism is false.

A first difficulty for Miller's analysis is this. Miller supposes that the mereological sum of $x$ and $y$ exists from $t_{1}$ to $t_{3}$. Yet, from an endurantist perspective, material entities fall under properties and relations in an inherently time-relative manner. Thus, a banana may be green at $t$ and yellow at a later time t'. But there is no sense in which the banana would be green and yellow simpliciter. Similarly for parthood: it is taken to be a three-place relation between a material entity, a part, and a time. As explained by Hawley (2001: 25) and Olson (2005: 5), the rejection of atemporal talk about parthood and other

\footnotetext{
${ }^{4}$ This reference and the following ones are to Miller (2008).

${ }^{5}$ Nota bene: as said by Miller in note 12 on page 59, the example is meant to cover the case where stuff is enduring.

${ }^{6}$ The sum of $x$ and $y$ is usually characterized as follows (cf. Varzi 2009: $§ 4.2$ ). This is the entity $z$ such that something overlaps $\mathrm{z}$ just in case it overlaps $\mathrm{x}$ or $\mathrm{y}$.
} 
mereological notions is a typical feature of endurance theory. ${ }^{7}$ Under such a conception, the mereological sum of two material entities exists only when both entities exist. In particular $\mathrm{z}$, the sum of $\mathrm{x}$ and $\mathrm{y}$, exists when and only when both $x$ and $y$ exist. That is, it exists from $t_{1}$ until $t_{2}$. At $t_{3}, x$ doesn't exist anymore, so neither does $\mathrm{z}$. But then, at any time at which it exists, $\mathrm{z}$ has the same parts (those of $x$ and $y$ and mereological sums thereof). Hence, $\mathrm{z}$ provides no counterexample to mereological essentialism for stuff.

Let us look at the problem from a slightly different angle. What intuitions are responsible for the belief in mereological essentialism for stuff and the belief in stuff composition? Concerning the former, as Miller writes (page 62), "the intuition is that if we remove some water from a portion of water, [what remains] is not the same portion of water." Concerning the latter, the intuition may be expressed in the following way. ${ }^{8}$ Imagine that some water $\mathrm{x}$ is on your left and some water $\mathrm{y}$ on your right. Then, when you consider $\mathrm{x}$ and $\mathrm{y}$ together, you still have some water, indeed, what seems to be a larger portion of water that you can describe as the water on your left and on your right. According to a popular view about mass nouns and stuff, this may be characterized as the mereological sum of $\mathrm{x}$ and $\mathrm{y}$. These two intuitions seem to apply for stuff of any given kind: they appear to be satisfied not only by water, but also by wine, gold, sand, etc. So we arrive at two principles. The first is that if you remove some stuff from a portion of stuff, what remains isn't the same portion of stuff. And generalizing this a bit further, we obtain mereological essentialism: if at some time $\mathrm{t}$, $\mathrm{x}$ exists and has certain parts (parts that exist at $t$ ), then at any other time $t$ ' at which $x$ also exists, the parts $\mathrm{x}$ has at $\mathrm{t}$ ' (parts that exist at $\mathrm{t}^{\prime}$ ) are the same than the parts $\mathrm{x}$ has at $t$. The second principle corresponds to a quite common understanding of stuff composition: at any given time, if there exists some stuff $\mathrm{x}$ and some distinct stuff $y$, then $\mathrm{x}$ and $\mathrm{y}$ together form a larger portion of stuff, $\mathrm{z}$, which can be characterized as their mereological sum. These two principles do not enter in conflict with each other. Inconsistency arises only when stuff composition is understood as somehow operating across time. Why should we think that stuff satisfies this kind of cross-temporal composition principle?

\section{Section 2}

Miller does not say why. So this key part of her argument is left unmotivated. Yet, as I will now show, language does allow us to refer to stuff that doesn't exist at the same time. Here is an example. Imagine that every month, John created some stuff (it may be some wine, or some water if John is a chemist), which was destroyed later in the same month. Knowing this, we can refer to the stuff John created in March, x, and to the stuff John created in April, y. And we can also refer to $\mathrm{x}$ and $\mathrm{y}$ as the stuff John created in March and in April, even if $\mathrm{x}$ and $\mathrm{y}$ do not exist at the same time. Under the popular conception of mass terms as denoting mereological sums, this definite description would then be taken to refer

\footnotetext{
${ }^{7}$ By contrast, according to perdurantists, a material entity is extended through time, just like an event, and has temporal parts (having them simpliciter). It is temporal parts themselves that are the primary bearers of properties, in a way that is not relative to time. Thus, the banana we considered would have two temporal parts. One part (corresponding to the period during which we would say that the banana is green) would be green, the other would be yellow.

${ }^{8}$ See for instance Gillon (1992: 597). The property is typically called cumulative reference.
} 
to the mereological sum of $\mathrm{x}$ and $\mathrm{y}$, since only this would ensure that mass terms have a uniform semantics, while treating various definite mass expressions in different ways would be ad hoc. So under that conception, the way we refer using mass nouns would constitute evidence in favor of mereological sums of things that do not exist at the same time and in favor of the cross-temporal principle of composition put forward by Miller.

However, the mereological view is not the only one. Under an alternative conception, mass nouns function semantically like plural terms: they can refer to several (enduring) things at once. Then the definite description the stuff John created in March and in April just refers to two entities, $\mathrm{x}$ and $\mathrm{y}$, which do not exist at the same time. There is nothing surprising in this: using plural expressions, we can talk of Caesar and Napoleon even if they existed at different periods. This seems more plausible than holding that something is the mereological sum of Caesar and Napoleon. Similarly for mass nouns if they function like plural terms: the expression the stuff John created in March and in April then refers to two entities, $\mathrm{x}$ and $\mathrm{y}$, that do not exist at the same time. There is no need to postulate that $\mathrm{x}$ and $\mathrm{y}$ would have a mereological sum. Indeed, under that conception, the thesis of stuff composition (which was previously understood as asserting the existence of the sum of any two portions of stuff) is reformulated as a thesis about how mass nouns refer. Let $M$ be a mass noun, like water or stuff. Whenever you can say of an entity $\mathrm{x}$ that it is some $\mathrm{M}$ and of a distinct entity $\mathrm{y}$ that it is some $\mathrm{M}$, you can also refer to $\mathrm{x}$ and $\mathrm{y}$ together as some M; doing so, you're just referring to two things, not one.

Miller quickly considers this kind of view on page 61. Following van Inwagen (1990) and Zimmerman (1995, section 9), she assumes atomism: a portion of stuff is a plurality of atoms (or simples), so that This stuff is part of that stuff just means that the atoms making up this stuff are among the atoms making up that stuff. So according to her, mereological essentialism should be replaced by a different, though analogous, principle. This principle says that if some stuff is made at $t$ of some things xs ("a plurality of things") and at t' of some things ys, then the xs and the ys are identical. Now, it is plain that this principle does not apply to all the stuff we can refer to: for the stuff John created in March and in April is made in March of things that are different from the things it is made of in April. In other words, the principle is not satisfied by "cross-temporal pluralities."

But if one is not atomist, then an independent notion of mereological part is needed, corresponding to the commonplace fact that a material entity may have parts. Consider the water in a bottle and the water in the lower half of the bottle. The latter is part of the former, just as the leg of a table is part of the table. So we need a relation of part applying in both cases. When atomism is not assumed, this relation cannot be reduced to the among relation between pluralities. Thus, Nicolas (2008) puts forward a semantics of mass nouns that uses both plural reference (explaining the intuition behind stuff composition by saying that a mass expression may refer to several things at once) and a notion of mereological part (to account for the fact that a material entity like the water in a bottle or a table may have parts). With such a notion of part, the basic intuition behind mereological essentialism can be expressed as follows, for any mass noun $M$. Suppose that at time $t$, an entity $\mathrm{x}$ is some $\mathrm{M}$ and $\mathrm{y}$ is part of $\mathrm{x}$. If we remove $\mathrm{y}$ from $x$, what remains is not the same $M$ (it is not identical to $x$ ). Generalizing, we 
arrive at mereological essentialism. Suppose an entity $\mathrm{x}$ is some $\mathrm{M}$ that exists at $\mathrm{t}$ and at $\mathrm{t}^{\prime}$. Then the parts $\mathrm{x}$ has at $\mathrm{t}$ (parts that exist at $\mathrm{t}$ ) are identical to the parts $\mathrm{x}$ has at t' (parts that exist at t'). This principle only concerns an entity and its parts. Now, when we talk of the stuff John created in March and in April, we are referring to (at least) two entities, the stuff John created in March, and the stuff he created in April. The principle of mereological essentialism, as just stated, does not apply to these entities referred to together. So it has nothing to say about the stuff John created in March and in April. And more generally, it does not enter in conflict with stuff composition, properly understood as the claim that a mass noun may be used to refer to several things at once.

\section{Acknowledgements}

For comments on earlier versions, I would like to thank Paul Egré, Kathrin Koslicki, Øystein Linnebo, Kristie Miller, Frédéric Nef, Thomas Sattig, Luc Schneider, Benjamin Spector, Mark Steen, and two anonymous referees. I also wish to express my gratitude to Florence and Henry, at whose cottage this and other works were partly written.

\section{References}

Gillon, B. (1992). 'Towards a Common Semantics for English Count and Mass nouns'. Linguistics and Philosophy 15: 597-639.

Hawley, K. (2001). How Things Persist. Oxford: Oxford University Press.

Markosian, N. (2004). 'Simples, Stuff, and Simple People'. The Monist 87(3): 405-421.

Miller, K. (2008). 'Essential Stuff'. Ratio 21(2): 55-63.

Miller, K. (2009). 'Stuff'. American Philosophical Quarterly 46(1): 1-18.

Nicolas, D. (2008). 'Mass Nouns and Plural Logic'. Linguistics and Philosophy 31(2): 211-244.

Olson, E. (2006). 'Temporal Parts and Timeless Parthood'. Nô̂s 40(4): 738-52. van Inwagen, P. (1990). Material Beings. Ithaca: Cornell University Press.

Varzi, A. (2009). 'Mereology'. The Stanford Encyclopedia of Philosophy (Summer 2009 Edition), E. N. Zalta (ed.), URL = <http://plato.stanford.edu/archives/sum2009/entries/mereology/>.

Zimmerman, D. W. (1995). 'Theories of Masses and Problems of Constitution'. Philosophical Review 104: 53-110. 